\title{
Stocking Rate and Weather Impacts on Sand Sagebrush and Grasses: A 20-Year Record
}

\author{
Robert L. Gillen and Phillip L. Sims \\ Authors are Rangeland Scientists, Southern Plains Range Research Station, USDA-ARS, 2000 18th St, Woodward, OK 73801.
}

\begin{abstract}
Understanding how stocking rate or grazing intensity affects the abundance of common plant species is fundamental to the sustainable management of rangelands. We had the unique opportunity to determine the impact of stocking rate on shrub canopy cover and grass basal cover in a sand sagebrush (Artemisia filifolia Torr.) grassland of the Southern Plains, United States. Treatments were imposed over a 20-year time span that included an entire precipitation cycle from wet to dry and back to wet conditions. From 1941 until 1951, continuous stocking treatments of 41, 53, and 82 animal-unit-days ha ${ }^{-1}\left(\mathrm{AUD} \cdot \mathrm{ha}^{-1}\right.$ ) were imposed with straight-bred Hereford steers (initial weight of $213 \mathrm{~kg} \pm 11 \mathrm{SE}$ ) for about 320 days from mid-November to late September of the next year. From 1952 through 1961, the experimental pastures were grazed yearlong by cow-calf pairs at 45, 60, and $87 \mathrm{AUD} \cdot \mathrm{ha}^{-1}$. Canopy cover of shrubs and basal cover of grasses were measured by the line-intercept method in 1940, 1942, 1949, 1955, 1958, and 1961. Canopy cover of sand sagebrush was not affected by stocking rate. Individual grass species exhibited positive and negative responses to stocking rate in some years, but no grass species responded to stocking rate in a single direction over the entire length of this long-term study. Stocking rate effects were most obvious under favorable conditions of high precipitation, but these effects were absent during drought. Climatic variability and slope gradient exerted the primary controlling influences on sand sagebrush-grasslands in the Southern Great Plains when stocking rates were within the bounds tested in this study.
\end{abstract}

\section{Resumen}

Entender como la carga animal o la intensidad de apacentamiento afecta la abundancia de las especies vegetales comunes es fundamental para el manejo sostenible de los pastizales. Tuvimos la oportunidad única de determinar el impacto de la carga animal en la cobertura de copa de los arbustos y la cobertura basal de los zacates en un pastizal de "sand sagebrush" (Artemisia filifolia Torr.) de las Planicies del Sur de Estados Unidos de América. Los tratamientos fueron impuestos sobre un periodo de tiempo de 20 años, el cual incluyó un ciclo entero de precipitación de húmedo a seco y de regreso a condiciones húmedas. De 1941 a 1951 los tratamientos de carga continua fueron 41, 53, y 82 unidades-animal-días ha ${ }^{-1}\left(\right.$ AUD $\cdot$ ha $\left.^{-1}\right)$ los que se impusieron con novillos puros de la raza Hereford (peso inicial de $213 \mathrm{~kg} \pm 11 \mathrm{EE}$ ) por aproximadamente 320 días de mediados de Noviembre a fines de Septiembre del año siguiente. De 1952 a 1961, los potreros experimentales fueron apacentados en forma continua por pares de vaca-becerro a 45,60 , y $87 \mathrm{AUD} \cdot \mathrm{ha}^{-1}$. La cobertura de la copa de los arbustos y la basal de los zacates fueron medidas con el método de intercepción de línea en 1940, 1942, 1949, 1955, 1958, y 1961. La cobertura de copa del "sand sagebrush" no fue afectada por la carga animal. En algunos años, las especies individuales de zacates mostraron respuestas positivas y negativas a la carga animal, pero a lo largo del estudio las especies de zacates no respondieron a la carga animal en una sola dirección. Los efectos de la carga animal fueron más obvios bajo condiciones favorables de alta precipitación y estuvieron ausentes durante la sequía. Cuando las cargas animal estuvieron dentro del los límites probados en este estudio, la variabilidad climática y el gradiente de pendiente fueron las principales influencias controladoras en el pastizales de "sand sagebrush" de la Grandes Planicies del Sur.

Key Words: grazing intensity, mixed prairie

\section{INTRODUCTION}

Understanding the relationships between stocking rate or grazing intensity and abundance of common plant species is

Names are necessary to report factually on available data; however, the USDA neither guarantees nor warrants the standard of the product, and the use of the name by the USDA implies no approval of the product to the exclusion of others that also may be suitable.

All programs and services of the US Department of Agriculture are offered on a nondiscriminatory basis without regard to race, color, national origin, religion, sex, age, marital status, or handicap.

Correspondence: Robert L. Gillen, USDA-ARS, 2000 18th St, Woodward, OK 73801. Email: bgillen@spa.ars.usda.gov

Manuscript received 16 January 2005; manuscript accepted 22 November 2005. fundamental to the sustainable management of rangelands. The general management paradigm is that taller grasses are replaced by shorter grasses as stocking rate increases (Briske 1996). This model was illustrated on sandhill rangeland in eastern Colorado when the shortgrass blue grama (Bouteloua gracilis [Willd. ex Kunth] Lag. ex Griffiths) increased while midgrasses needleandthread (Hesperostipa comata [Trin. \& Rupr.] Barkworth) and prairie sandreed (Calamovilfa longifolia [Hook.] Scribn.) decreased as cattle stocking rates increased 
(Sims et al. 1976). However, stocking rate had little impact on the species composition of grasses on sandhill rangeland grazed by cattle in western Nebraska (Burzlaff and Harris 1969).

Climatic fluctuations, particularly in precipitation, are a fundamental feature of rangeland ecosystems. Such fluctuations often have major effects on the composition of grassland communities (Albertson and Tomanek 1965; Mihlbacher et al. 1989; Fuhlendorf and Smeins 1997). Ellis and Swift (1988) argued that stochastic climatic effects completely negate stocking rate effects on arid and semiarid rangelands. Illius and O'Conner (1999) countered that vegetation response is coupled to grazing intensity even in ecosystems with highly variable precipitation, but the strength of the coupling is greater for more productive sites within a grazing unit and during high precipitation periods. Olson et al. (1985) concluded climatic effects were dominant but that the responses of individual species to climate were mediated by stocking rate. Fuhlendorf et al. (2001) found that stocking rate determined the long-range trajectory of grassland succession but that climatic fluctuations could either strengthen existing trajectories or promote alternate trajectories.

A research project was initiated in 1940 at the Southern Plains Experimental Range, Woodward, Oklahoma, to determine stocking rates for the sand sagebrush (Artemisia filifolia Torr.) mixed prairie of the southern Great Plains that would sustain production of beef cattle while improving or maintaining plant and soil resources. The impacts of stocking rate on livestock performance and economic returns (Shoop and McIlvain 1971; Sims and Gillen 1999; Gillen and Sims 2002), herbaceous plant production (Gillen and Sims 2004), and water infiltration into the soil (Rhoades et al. 1964) have been reported previously. This paper reports the responses of canopy cover of sand sagebrush and basal cover of grasses to different stocking rates over a 20 -year study period. The primary hypotheses were that sand sagebrush would increase and taller grasses would be replaced by shorter grasses over time as stocking rate increased.

\section{MATERIALS AND METHODS}

The research was conducted at the Southern Plains Experimental Range located in northwestern Oklahoma, $27 \mathrm{~km}$ northwest of Woodward (lat $36^{\circ} 37^{\prime} \mathrm{N}$, long $99^{\circ} 35^{\prime} \mathrm{W}$, elevation 610 $640 \mathrm{~m})$. The long-term (1915-2003) average precipitation is $576 \mathrm{~mm}$ with $77 \%$ of this amount occurring during the April to October growing season.

The landscape consists of gently rolling, stabilized sand dunes. Drainage patterns are not well defined. Eda loamy sands (formerly designated as Pratt; mixed, thermic Lamellic Ustipsamments) are on lower slopes and more level areas, and Tivoli fine sands (mixed, thermic Typic Ustipsamments) occur on upper slopes. The vegetation is dominated by sand sagebrush. The herbaceous understory is a mixture of tall, mid-, and short warm-season grasses and forbs. This vegetation is an example of the sand sagebrush-mixed prairie cover type that dominates landscapes along major rivers flowing across the Southern Plains (Berg 1994).

Prior to the study initiation, the entire area was grazed as a single pasture. The vegetation was considered to be in poor condition in 1936 because of the effects of heat, the drought of the 1930s, and excessive forage utilization (Savage et al. 1941). Grazing was deferred during the entire growing season in 3 of the next 5 years, including 1941. By the time grazing treatments were imposed in December 1941, the vegetation was "characterized by maximum development of all species of grass with the taller species largely overshadowing and obscuring the fairly thick and rather uniform stand of sand sagebrush" (Savage et al. 1941).

\section{Experimental Treatments}

Grazing treatments consisting of 3 levels of continuous stocking were initiated in late 1941 . For the 1941 to 1951 period, the stocking rate for yearling beef cattle was 41,53 , and 82 animalunit-days (AUD) $\cdot \mathrm{ha}^{-1} \cdot \mathrm{y}^{-1}$. These stocking rates were labeled qualitatively as light grazing, moderate grazing, and overgrazing, respectively (Savage et al. 1941). Each steer was 0.67 animal unit, based on average initial weight of $213 \mathrm{~kg} \pm 11 \mathrm{SE}$ and an average gain of $168 \mathrm{~kg} \cdot$ head $^{-1}$ for the 320 -day grazing season, from mid-November to late September of the following year. From 1952 to 1961, the grazing treatments were changed to year-round cow-calf grazing. The stocking rates were increased slightly to 45,60 , and $87 \mathrm{AUD} \cdot \mathrm{ha}^{-1} \cdot \mathrm{y}^{-1}$. There were 2 replications of each level of stocking rate. Experimental pastures ranged in size from 43 to 86 ha.

\section{Vegetation Surveys}

Canopy cover of shrubs and basal cover of herbaceous plants were measured in 1940 before the grazing studies began, and in 1942, 1949, 1955, 1958, and 1961 using the line-transect method of Parker and Savage (1944). Each pasture was subdivided into 5 strata, which were parallel bands of equal width that stretched across the entire pasture. Within each stratum, a sampling line parallel to the long-axis of the stratum was randomly chosen. The same sampling lines were used in each survey. Observers paced the sampling lines with the aid of a compass and periodically established $10-\mathrm{m}$ line transects that were spaced evenly along, and parallel to, the sampling lines. The number of transects placed along each sampling line was proportional to the length of that sampling line compared to the total length of all sampling lines in the same pasture. The 10 - $\mathrm{m}$ line transects were not permanently marked. The number of line transects sampled in each pasture averaged about 200 from 1940 to 1955 and about 130 in 1958 and 1961.

Shrub canopy cover was measured in a $10-\mathrm{cm}$ band along the $10-\mathrm{m}$ transect cable, which was tightly stretched just above the shrub canopy. Shrub branches equal to or less than $10 \mathrm{~cm}$ apart were considered solid foliage cover. If a shrub had canopy gaps of greater than $10 \mathrm{~cm}$, the cover of individual portions was summed and recorded as a single measure for that shrub. After the shrubs were measured, the cable was lowered to ground level, and the basal cover of all herbaceous plants was measured in a $1-\mathrm{cm}$ band along the cable. When parts of an herbaceous plant were closer than $1 \mathrm{~cm}$, they were considered solid ground cover. If a plant had basal cover gaps of greater than $1 \mathrm{~cm}$, the covers of individual portions were summed and recorded as a single measure for that plant. This gave a record of basal cover as well as the total number of plants along each $10-\mathrm{m}$ transect. The minimum cover entered for any individual 
Table 1. Plant species included in the analyses and their cover averaged over slope category, stocking rate, and year. Cover is canopy cover for sand sagebrush and basal cover for grasses.

\begin{tabular}{llc}
\hline Common name & \multicolumn{1}{c}{ Scientific name } & $\begin{array}{c}\text { Average cover } \\
(\%)\end{array}$ \\
\hline $\begin{array}{l}\text { Sand sagebrush } \\
\text { Blue grama }\end{array}$ & $\begin{array}{l}\text { Artemisia filifolia Torr. } \\
\text { Bouteloua gracilis (Willd. ex Kunth) }\end{array}$ & 37.4 \\
Land dropseed & Sporobolus cryptandrus (Torr.) Gray & 2.76 \\
Little bluestem & Schizachyrium scoparium (Michx.) Nash & 1.51 \\
Sand lovegrass & Eragrostis trichodes (Nutt.) Wood & 0.65 \\
Sand paspalum & Paspalum setaceum Michx. & 0.47 \\
Purple sandgrass & Triplasis purpurea (Walt.) & 0.44 \\
& $\quad$ Chapman & 0.36 \\
Fall witchgrass & Digitaria cognata var.cognata & \\
& (J. A. Schultes) Pilger & 0.32 \\
Schweinitz's flatsedge & Cyperus schweinitzii Torr. & \\
Sand bluestem & Andropogon hallii Hack. & 0.31 \\
\hline
\end{tabular}

plant was $1 \mathrm{~cm}$. Slope gradient was measured at each transect using an Abney level.

\section{Data Analyses}

Analyses of individual grass species were limited to those contributing a minimum of $5 \%$ of relative grass cover in at least one year and slope category. Table 1 lists the species analyzed and their absolute basal cover averaged over stocking rate, slope category, and year. Schweinitz's flatsedge is a member of the Cyperaceae but, for brevity, will be discussed as a grass in this paper. Total basal cover of perennial grasses also was analyzed. Purple sandgrass contributed $82 \%$ of the annual grass cover and was the only annual grass analyzed. Similarly, sand sagebrush contributed $96 \%$ of the total shrub cover and was the only shrub species analyzed. Other annual grass and shrub species were too rare for meaningful analyses.

Slope gradient was incorporated into the analyses by delineating 5 categories: $0 \%-1 \%, 2 \%-5 \%, 6 \%-12 \%$, greater than $12 \%$, and dune top $(0 \%-5 \%)$. Each transect was classified into the appropriate category, and data from all transects within a given slope category and pasture were averaged. Slope category within pasture was the experimental unit for all analyses.

The data were analyzed using the MIXED procedures of SAS (SAS Institute Inc 1999) with a completely randomized design model testing the effects of stocking rate, slope, and their interactions, with year treated as a repeated measure. All tests were evaluated with $\alpha=0.05$. When significant treatment effects were detected, least squares means were compared with pairwise tests using Tukey's adjustment for multiple comparisons (SAS Institute Inc 1999).

The transect data from 1940 served as control data because the entire study area was grazed as a single large pasture until the stocking rate treatments were imposed in late 1941. To interpret grazing effects, the stocking rate by year interaction was of primary importance. The occurrence of a significant stocking rate main effect in the analysis of variance without a stocking rate by year interaction indicated that the species of interest was not actually affected by stocking rate. Such a result

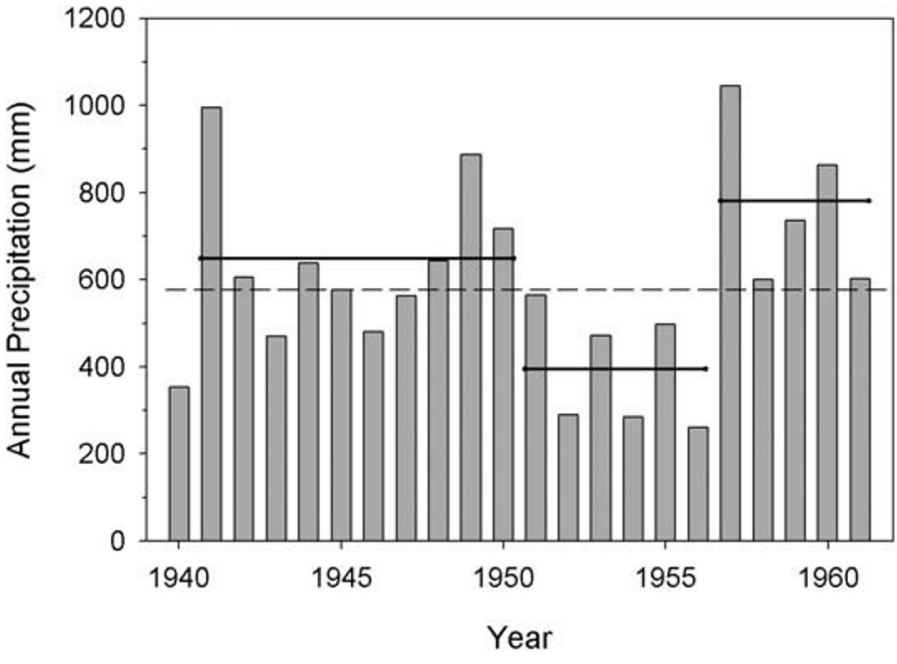

Figure 1. Annual precipitation (mm) from 1940 to 1961 at the Southern Plains Experimental Range, Woodward, OK. Solid lines represent average precipitation for the designated periods. The dashed line represents the long-term average (1915-2003).

suggests that there was a relationship between cover and stocking rate in 1940, before treatments were imposed, and the relationship was not changed by stocking rates applied after 1940. We assume that any significant relationship present between species cover and stocking rate in 1940 was a chance relationship. If this relationship did not change over time (no stocking rate $\times$ year interaction), there was no stocking rate effect. If the stocking rate by year interaction was significant for a given species, the cover of that species reacted differently over time depending on the stocking rate. This indicated a true stocking rate effect.

\section{RESULTS}

\section{Precipitation}

Just prior to the initiation of the study, the region experienced a major drought. From 1933 to 1940, precipitation was below average in every year except 1938 with an average shortfall of $21 \%$ from the long-term mean. During the actual study period, precipitation patterns can be grouped into 3 distinct periods (Fig. 1). Precipitation from 1941 to 1950 averaged $648 \mathrm{~mm}$, which is $13 \%$ above the long-term average of $576 \mathrm{~mm}$. A severe drought occurred from 1951 until 1956. During that period, annual precipitation averaged $394 \mathrm{~mm}$, about $69 \%$ of the longterm average, dormant season precipitation was consistently below the norm, and growing season rainfall exceeded the average only in 1955. The drought ended in 1957 when 1044 $\mathrm{mm}$ of precipitation was received, the greatest amount on record. Annual precipitation averaged $777 \mathrm{~mm}$ from 1957 to $1961,35 \%$ above the long-term mean, and was above average every year. The study, therefore, encompassed an entire precipitation cycle from wet to dry and back to wet conditions. Over the full course of the study, annual precipitation was $6 \%$ above the long-term mean. The years with the lowest (1954) and highest (1957) precipitation that have been recorded at the study site occurred during the study. 


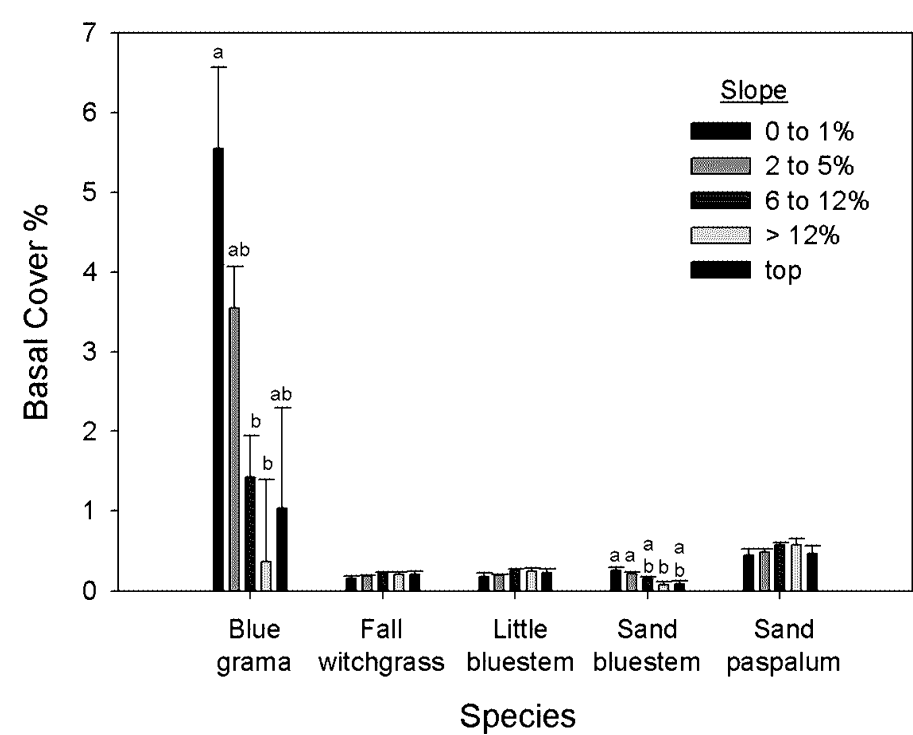

Figure 2. Basal cover of blue grama, fall witchgrass, little bluestem, sand bluestem, and sand paspalum as affected by slope gradient at the Southern Plains Experimental Range, Woodward, OK. Data averaged over stocking rate and year. Bars are standard errors. Different letters designate significant differences among slope categories $(P \leq 0.05)$.

\section{Slope Gradient}

Slope gradient had a strong influence on the organization of this mixed grassland. Fall witchgrass $(P=0.32)$, little bluestem $(P=0.23)$, and sand paspalum $(P=0.43)$ were the only species not affected by slope gradient (Fig. 2). Basal cover of blue grama $(P=0.003)$ and sand bluestem $(P=0.005$; Fig. 2$)$ declined as slope gradient increased (Fig. 2), and there was no slope gradient by year interaction for these species $(P=0.08$ and 0.79 , respectively).

Interactions of slope gradient and year were found for the other species analyzed. Sand dropseed basal cover was greater on lower slope gradients during the first 4 measurement periods $(P=0.0001$ for slope $\times$ year, Fig. 3). Cover of Schweinitz's flatsedge was similar across slopes in 5 of 6 years, but was greater on lower slopes when this species exhibited a large overall increase in cover in $1958(P=0.0003$ for slope $\times$ year; Fig. 3). Conversely, in years when differences occurred, cover increased as slope gradient increased for sand sagebrush, purple sandgrass, and sand lovegrass $(P=0.03,0.0002$, and less than 0.0001 , respectively, for slope $\times$ year; Fig. 3$)$.

\section{Stocking Rate}

Canopy cover of sand sagebrush was different among stocking rates $(P=0.05)$ averaging $36.0 \%, 39.6 \%$, and $39.3 \%$ over years at stocking rates of 45,60 , and $87 \mathrm{AUD} \cdot \mathrm{ha}^{-1}$, respectively. However, there was no stocking rate by year interaction $(P=0.80$; Fig. 4$)$, indicating the differences in sagebrush canopy cover were present in 1940 before stocking rate treatments were imposed and did not change over the course of the study. Sand sagebrush was not differentially affected by stocking rate. Canopy cover of sand sagebrush was influenced by year $(P<0.0001)$, which is assumed to be weather related, and these fluctuations over time were similar among stocking rates (Fig. 4).
The basal cover of perennial grasses was not related to stocking rate $(P=0.46)$, and there was no stocking rate by year interaction $(P=0.29$; Fig. 4$)$. There were no stocking rate effects (range of $P=0.16-0.88$ ) and no stocking rate by year interactions ( $P$ range 0.39-0.97; Fig. 5) for basal cover of blue grama, fall witchgrass, little bluestem, sand bluestem, Schweinitz's flatsedge, or purple sandgrass, but these species did fluctuate over years $(P<0.0001$ for all species; Fig. 5).

Basal cover of sand dropseed was affected by the interaction of stocking rate and year $(P=0.01$; Fig. 5). Sand dropseed basal cover was greatest at $60 \mathrm{AUD} \cdot \mathrm{ha}^{-1}$ in 1940 and 1942, but this affect is assumed to be related to random initial pasture conditions since stocking rate treatments were not imposed until 1941. Sand dropseed increased and became most abundant at a stocking rate of 87 AUD $\cdot \mathrm{ha}^{-1}$ from 1942 to 1949 while remaining constant over this period at the 45 and 60 AUD $\cdot \mathrm{ha}^{-1}$ stocking rates. During the drought of the 1950's, sand dropseed basal cover converged among stocking rates, and no stocking rate effect could be detected over the latter half of the study. Sand dropseed was the only perennial grass that did not decrease during the drought.

Basal cover of sand lovegrass and sand paspalum were also affected by the interaction of stocking rate and year $(P<0.0001$ and $P=0.0003$, respectively; Fig. 5). At the end of the 2 wet periods, 1949 and 1961, sand lovegrass was inversely related to stocking rate and responded as a decreaser to grazing intensity. Sand paspalum was directly related to stocking rate and responded as an increaser during the last measurement period of the experiment.

There were no slope gradient by stocking rate interactions for any species ( $P$ range $0.43-0.99$ ), indicating that stocking rate effects were independent of slope gradient.

\section{DISCUSSION}

\section{Sagebrush Response}

Canopy cover of sand sagebrush was not affected by stocking rate over the course of this study. Cover averaged about 3.5 percentage units less at $45 \mathrm{AUD} \cdot \mathrm{ha}^{-1}$ compared to 60 and $87 \mathrm{AUD} \cdot \mathrm{ha}^{-1}$, but this difference was already present before the stocking rate treatments were imposed. In adjacent pastures grazed only in the growing season with either continuous or rotational stocking, stocking rate also did not affect canopy cover of sand sagebrush (McIlvain and Savage 1951). In contrast, Sims et al. (1976) reported an increase in sand sagebrush canopy cover at stocking rates of 36 and 56 AUD $\cdot \mathrm{ha}^{-1}$ compared to $19 \mathrm{AUD} \cdot \mathrm{ha}^{-1}$ after 11 years in eastern Colorado. However, the initial levels of sagebrush cover at the Colorado site $(4 \%-6 \%)$, and the changes over years (1.5-2 percentage units) were much smaller than at this Oklahoma site.

\section{Stocking Rate Versus Weather}

No grass species displayed a consistent, directional response to the stocking rates used in this study over the entire 20-year measurement period. Basal cover of 6 of the 9 grasses was not affected by stocking rate at any time during the study. The basal cover of 2 of 9 grasses, sand dropseed and sand lovegrass, was 

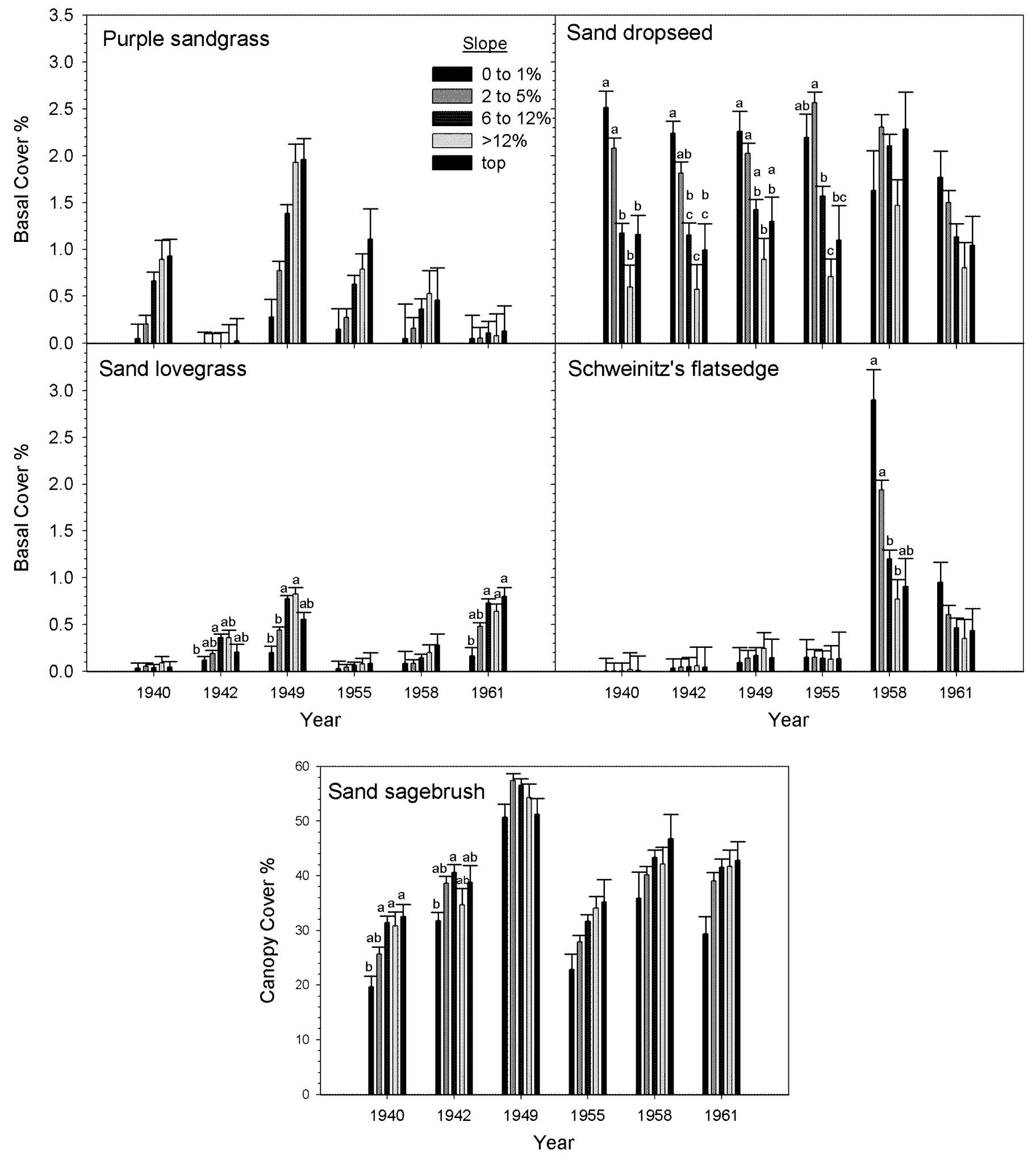

Figure 3. Basal cover of purple sandgrass, sand lovegrass, sand dropseed, and Schweinitz's flatsedge, and canopy cover of sand sagebrush as affected by the interaction of slope gradient and year at the Southern Plains Experimental Range, Woodward, OK. Data averaged over stocking rate. Bars are standard errors. Different letters designate significant differences among slope categories within year $(P \leq 0.05)$.

affected by stocking rate in 1949 , at the end of a relatively wet period. However, the ensuing drought eliminated the stocking rate effect. No grasses were affected by stocking rate in 1958, the first sample year after the severe drought of 1952-1956. In
1961, following 20 years of differential stocking rates, the basal cover of only 2 grasses, sand lovegrass and sand paspalum, differed in response to stocking rate. Cover of sand lovegrass was smaller at the higher stocking rates, whereas sand 


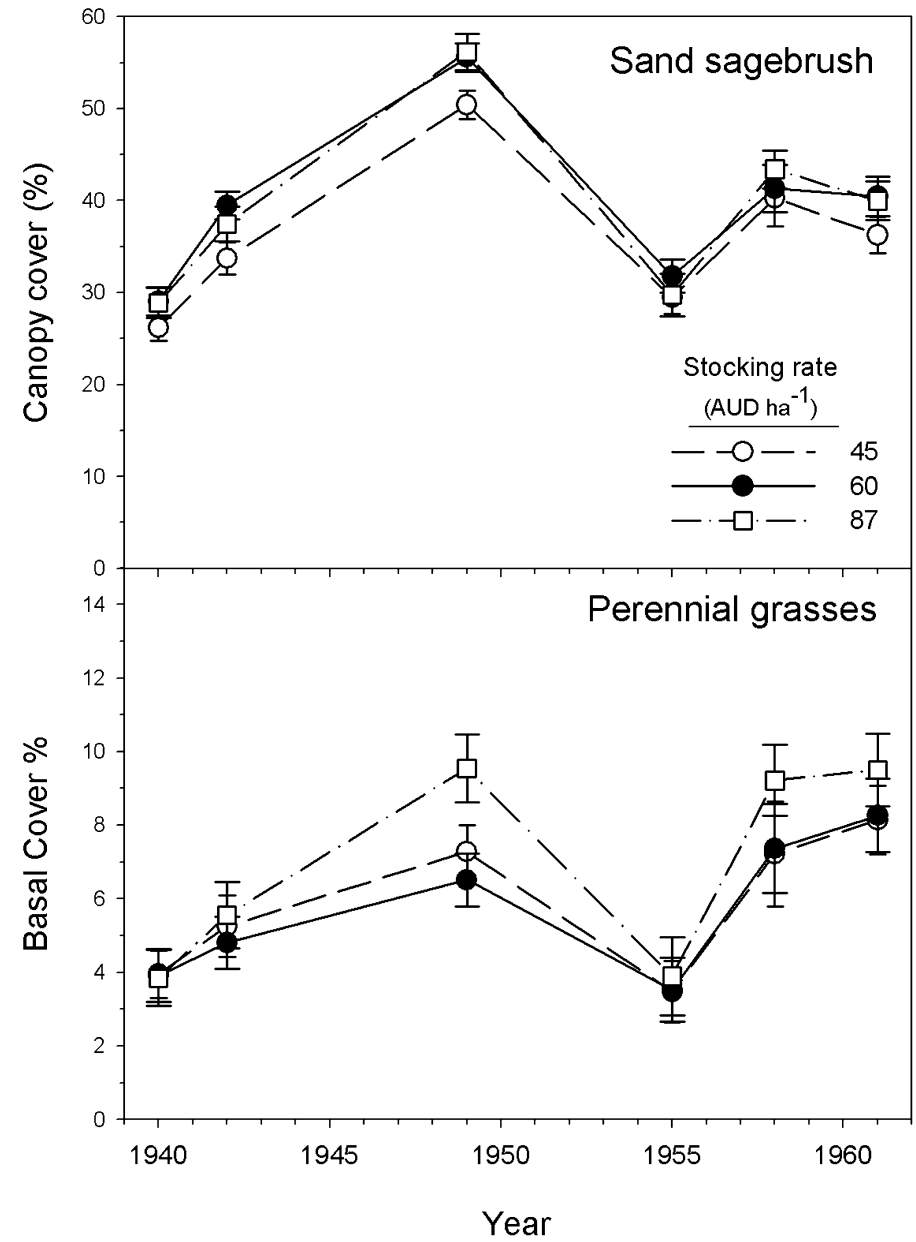

Figure 4. Canopy cover of sand sagebrush and basal cover of perennial grasses as affected by the interaction of stocking rate and year at the Southern Plains Experimental Range, Woodward, OK. Data are averaged over slope gradient. Bars are standard errors. Main effect of stocking rate is significant for sand sagebrush $(P=0.05)$ but not perennial grasses $(P=0.46)$. The stocking rate by year interaction is not significant for either component $(P=0.80$ for sand sagebrush; $P=0.29$ for perennial grasses).

paspalum showed the opposite response with greater basal cover at the higher stocking rates.

In contrast, all grass species experienced changes in basal cover over years. These year-to-year changes are assumed to be driven mainly by weather. Individual grass species had variable patterns of change over years. For instance, Schweinitz's flatsedge had a dramatic but short-lived increase in cover in 1958. Sand paspalum tended to increase throughout the study with accelerated changes during the last wet period. Purple sandgrass increased during the first wet period, but not the second. These temporal changes are examples of nondirectional dynamics driven by individualistic species responses to environmental variability, a phenomenon also observed by Olson et al. (1985).

Illius and O'Conner (1999) felt that vegetation response would be more tightly coupled to grazing intensity during periods of higher precipitation. Our results lend some support to this hypothesis. For the species that did respond to stocking rate, the differences were seen only in 1949 or 1961, both at the end of favorable precipitation periods. However, the great majority of species in this study did not respond to stocking rate at all, regardless of precipitation. Fuhlendorf et al. (2001) found that grazing intensity determines the long-term trajectory of grassland species composition, but shorter-term climatic variability modifies the overall trajectory. In contrast, climatic variability was more of a controlling influence than stocking rate on sand sagebrush grasslands in the Southern Great Plains within the bounds of the stocking rates and duration of treatment imposed in this study. Biondini et al. (1998) reported similar results for a northern mixed-grass prairie.

Resistance has been defined as the capacity of a system to continue to function without change through a disturbance (Pimm 1984). There are many measures of ecosystem function, but in terms of shrub canopy and grass basal cover, we conclude this sand sagebrush-grassland was rather resistant to stocking rate effects over the length of a complete wet-dry cycle. This resistance was also confirmed by the similarity of herbaceous plant production among stocking rates in the final 4 years of this study (Gillen and Sims 2004).

\section{MANAGEMENT IMPLICATIONS}

Although basal cover was little affected by stocking rate, herbaceous standing crop at any given point in time was smaller in pastures with higher stocking rates, and these differences were visually obvious. Such differences could impair nesting and hiding cover for wildlife even though basal cover of the grasses was generally unaffected. Wind and water erosion appeared to increase at the highest stocking rate (Shoop and Mcllvain 1971). This suggests potential long-term declines in productivity, but any such changes would apparently require more than 20 years to develop.

Torell et al. (1991) found that sand sagebrush-grasslands in eastern Colorado could be grazed at stocking rates that maximized net economic returns from yearling cattle while still maintaining plant productivity and composition. This was also the case for cow-calf grazing in the current study because net returns were maximized at $63 \mathrm{AUD} \cdot \mathrm{ha}^{-1}$ (Gillen and Sims 2002), which was within the range of stocking rates that sustained the grass community in the current study. Under the conditions of this study, grazing at stocking rates up to $87 \mathrm{AUD} \cdot \mathrm{ha}^{-1}$ would not result in strong directional changes in the canopy cover of shrubs or the basal cover of grasses, but stocking rates above $65 \mathrm{AUD} \cdot \mathrm{ha}^{-1}$ would reduce net returns and likely have negative impacts on cover for wildlife.

\section{ACKNOWLEDGMENTS}

The authors acknowledge the contributions of D. A. Savage (deceased) who designed and implemented this research. Retired rangeland scientists E. H. McIlvain and M. C. Shoop were responsible for much of the field work. The cattle used in this study were supplied by the Pecos Anderson Family, owners, Canadian River Cattle Co, Canadian, Texas. 


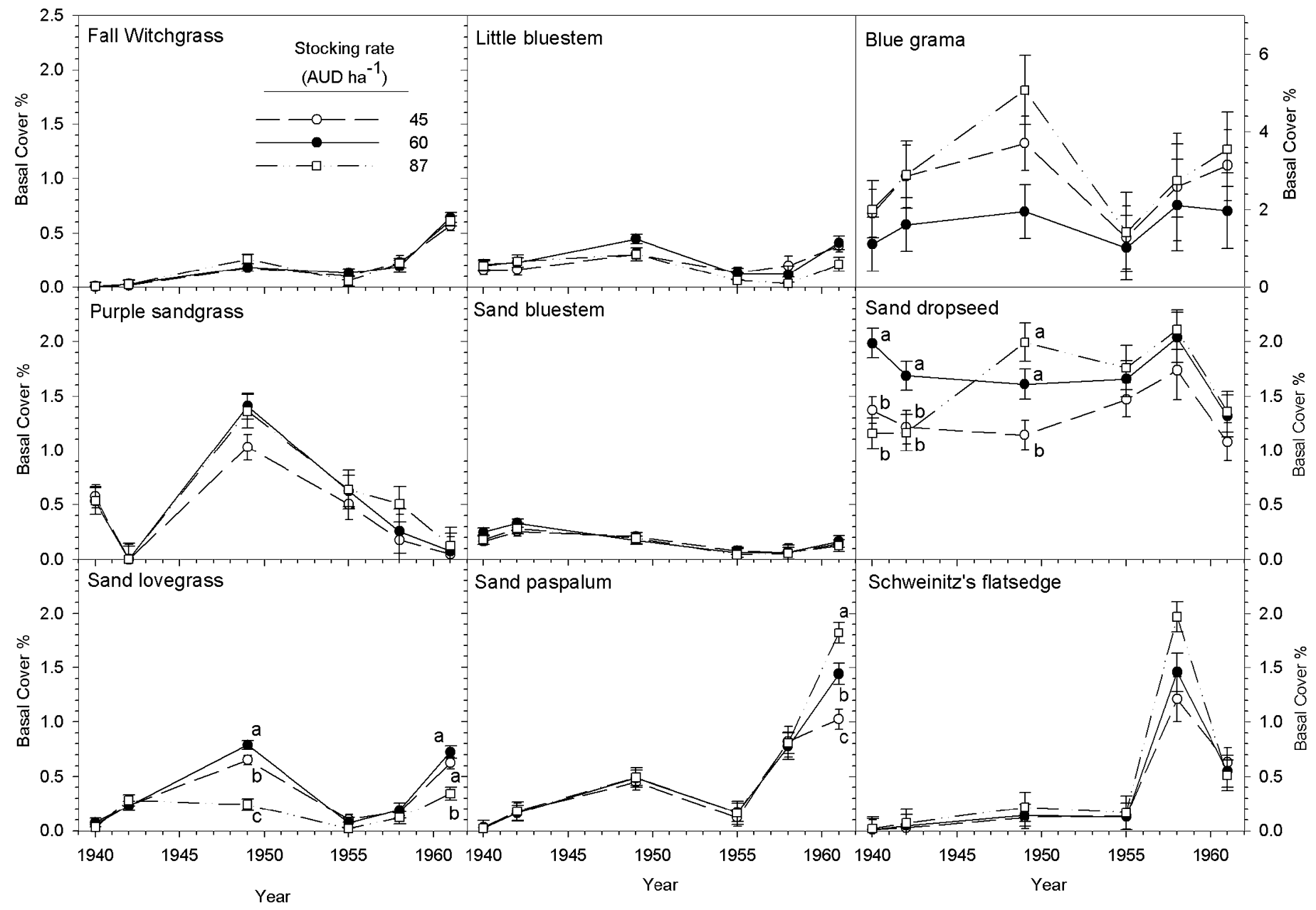

Figure 5. Basal cover of grasses as affected by the interaction of stocking rate and year at the Southern Plains Experimental Range, Woodward, OK. Data are averaged over slope gradient. Bars are standard errors. Different letters designate significant differences among stocking rates within year $(P \leq 0.05)$. Note different scale for cover of blue grama.

\section{LITERATURE CITED}

Albertson, F. W., and G. W. Tomanek. 1965. Vegetation changes during a 30 -year period in grassland communities near Hays, Kansas. Ecology 46: 714-720.

BeRG, W. A. 1994. Sand sagebrush—mixed prairie. In: T. N. Shiflet (ED.) Rangeland cover types of the United States. Denver, CO: Society for Range Management. p 99.

Biondini, M. E., B. D. Patton, and P. E. Nyren. 1998. Grazing intensity and ecosystem processes in a northern mixed-grass prairie, USA. Ecological Applications 8:469-479.

BRISKE, D. D. 1996. Strategies of plant survival in grazed systems: a functional interpretation. In: J. Hodgson and A. W. Illius (EDS.). The ecology and management of grazing ecosystems. New York, NY: CAB International. p 37-67.

BuRzLAFF, D. F., AND L. HaRRIS. 1969. Yearling steer gains and vegetation changes of western Nebraska rangeland under three rates of stocking. Station Bulletin SB 505. Lincoln, NE: Nebraska Agricultural Experiment Station. $19 \mathrm{p}$.

Ellis, J. E., AND D. M. SwIFt. 1988. Stability of African pastoral ecosystems: alternate paradigms and implications for development. Journal of Range Management 41:450-459.

Fuhlendorf, S. D., D. D. Briske, and F. E. Smeins. 2001. Herbaceous vegetation change in variable rangeland environments: the relative contribution of grazing and climatic variability. Applied Vegetation Science 4:177-188.
Funlendorf, S. D., AND F. E. Smeins. 1979. Long-term vegetation dynamics mediated by herbivores, weather and fire in a Juniperus-Quercus savanna. Journal of Vegetation Science 8:819-828.

Gillen, R. L., AND P. L. Sims. 2002. Stocking rate and cow-calf production on sand sagebrush rangeland. Journal of Range Management 55: $542-550$.

Gillen, R. L., AND P. L. Sims. 2004. Stocking rate, precipitation, and herbage production on sand sagebrush-grassland. Journal of Range Management 57:148-152.

Illius, A. W., AND T. G. O'Conner. 1999. On the relevance of nonequilibrium concepts to arid and semiarid grazing systems. Ecological Applications 9: 798-813.

Mcllvain, E. H., And D. A. Savage. 1951. Eight-year comparisons of continuous and rotational grazing on the Southern Plains Experimental Range. Journal of Range Management 4:42-47.

Minlbacher, B. S., F. E. Smeins, G. W. Thomas, and C. A. Taylor. 1989. Long-term grass dynamics within a mixed-grass prairie. Proceedings of the Eleventh North American Prairie Conference; Lincoln, NE. 11:25-28.

Olson, K. C., R. S. White, and B. W. Sindelar. 1985. Response of vegetation of the Northern Great Plains to precipitation amount and grazing intensity. Journal of Range Management 38:357-361.

Parker, K. W., and D. A. Savage. 1944. Reliability of the line interception method in measuring vegetation on the Southern Great Plains. Agronomy Journal 36: 97-110. 
PImm, S. L. 1984. The complexity and stability of ecosystems. Nature 307: 321-326.

Rhoades, E. D., L. F. Locke, H. M. Taylor, and E. H. Mclıvain. 1964. Water intake on a sandy range as affected by 20 years of differential cattle stocking rates. Journal of Range Management 17:185-190.

SAS InSTITUTE Inc. 1999. SAS/STAT user's guide, version 8. Cary, NC: SAS Institute Inc. $3884 \mathrm{p}$.

Savage, D. A., M. L. Peterson, JR, E. H. Mcllvain, and R. E. Solomon. 1941. Preliminary report or brief summary of work project, line project, and subproject investigations with grasses, legumes, and other forage crops. Woodward, OK: USDA-Bureau of Plant Industry, Southern Great Plains Field Station.
Shoop, M. C., And E. H. Mclıvain. 1971. Why some cattlemen overgraze-and some don't. Journal of Range Management 24:252-257.

Sims, P. L., B. E. Dahl, and A. H. Denham. 1976. Vegetation and livestock response at three grazing intensities on sandhill rangeland in eastern Colorado. Technical Bulletin 130. Ft. Collins, C0: Colorado Agricultural Experiment Station. $48 \mathrm{p}$.

Sims, P. L., And R. L. Gillen. 1999. Rangeland and steer responses to grazing in the Southern Plains. Journal of Range Management 55:651-660.

Torell, L. A., K. S. Lyon, AND E. B. Godfrey. 1991. Long-run versus short-run planning horizons and the rangeland stocking rate decision. American Journal of Agricultural Economics 73:795-807. 